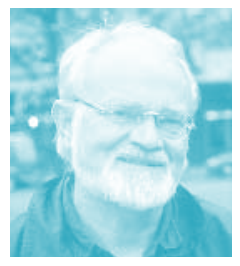

Hans Knut Otterstad, lege og helsetjenesteforsker.

\title{
Hva kan vi lære av
} svensk samhandling?

\author{
Den svenske samhandlingsreformen har flere fortrinn, \\ blant annet et velfungerende elektronisk informasjonssystem.
}

D en vedtatte samhandlingsreformen er først og fremst et politisk drevet prosjekt, men det er tuftet på praktisk medisinsk- og pleiefaglig arbeid. En slik reform krever gode systemer både på organisasjons- og styringsnivå, men først og fremst trengs det effektive rutiner og samarbeid om den enkelte pasient. En sammenlikning mellom samhandlingssystemer og praksis i Norge og Sverige egner seg godt for forbedringsarbeid og læring siden de kulturelle og politiske forhold er relativt like. Det er likevel forskjeller i praksis som bør dokumenteres. Det er viktig å ha kunnskap om det svenske systemet siden dette arbeidet startet tidligere hos våre naboer. Og ved å vite mer kan en trolig unngå begynnertabber når den norske samhandlingsreformen starter 1.1.2012.

\section{Likheter}

Den største likhet er at det i helsetjenesten går et avgjørende skille for behandlingsansvar mellom kommuner og sykehus. Sykehusene drives riktignok av staten i Norge og av fylkene eller «lenene» $\mathrm{i}$ Sverige, men dette innebærer samme type samarbeidsutfordring for den pasientgruppen som i begge land kalles «utskivingsklare». Svaret på fire sentrale spørsmål vil avgjøre om samhandlingen om disse pasientene vil lykkes i Norge:

1) Hvem bestemmer inklusjonskriteriene for disse pasientene?

2) Hvordan skal informasjonsflyten organiseres?

3) Hvordan ordes møteplassene mellom fagfolkene?

4) Hvordan sikrer man en behandlingskjede som oppleves som trygg både for fagfolk, pasient og pårørende?

I denne rapporten vil de svenske løsningene bli beskrevet og deretter sammenliknet med de norske. Siden det kan være regionale forskjeller vil jeg sammenlikne samhandlingssystemene i to administrative områder: Dalarna len og Østfold fylke. turhenvisninger på våre nettsider.

\section{Søkeord:}

I Kommunehelsetjeneste

I Spesialisthelse-

tjeneste

I Samhandling

) Norden

\section{«Samordnad vårdplanering»}

I Sverige er det utviklet et formelt og detaljert regelverk for samhandling. I Sverige kalles metoden for «Samordnad vårdplannering». Dette er et mer presist begrep enn samhandling, siden fagfolkene arbeider på hver sin side av «gjerdet», med klart definerte arbeidsoppgaver og tilhørende personell. Utfordringen er å få de to systemene til å passe sammen. Målsettingen er at det skapes synergier og ikke gråsone-konflikter som vanskeliggjør effektiv drift langs en definert behandlingskjede med to forvaltningsnivåer. For å få til dette i praksis har Landstinget i Dalarna sammen med de 14 kommunene som sokner til hospitalet i Falun laget et samarbeidsdokument som kalles «Samordnad vårdplanering» (SVP) (1). Dette inneholder et detaljert og bindende regelverk. Et grunnleggende aspekt er at det skal finnes felles rutiner for en pleieplan (vårdplan) som skal sikre pasientens rett til trygghet, delaktighet og innflytelse når de ulike tiltak planlegges og gjennomføres.

\section{Organisering}

Hvem deltar i den samordnete planleggingen? Falun kommune og Dalarna len har utarbeidet et felles dokument som regulerer samhandlingen (2). De viktigste elementene er:

I SVP skal alltid skje i samråd med den enkelte pasient og dennes nærstående.

I Utskrivende lege har ansvar for å kalle inn til SVP.

, Ved SVP bør alltid pasient og pårørende, den ansvarlige lege for behandlingen i kommunen, en kommunal sykepleier, arbeidsterapeut, fysioterapeut og distriktssykepleier delta. En «bistandshandleggare» fra kommunen deltar alltid. «Det är han/hon som planerar och beviljar vilka insatser som patienten behöver från kommunen i hemmet efter utskrivning från sjukhuset», heter det i dokumentet.

Samarbeidsdokumentet bygger på flere hovedprinsipper og tar utgangspunkt $\mathrm{i}$ at en pasient er utskrivingsklar. Utskrivingsklar blir definert slik: Når den behandlende lege (på sykehuset) bedømmer at pasienten ikke lenger behøver behandling på sykehusnivå.

Ansvarsfordeling: Legen på sykehusnivå er suveren i sin vurdering og beslutning om behandlingsnivå, mens fagfolk på kommunenivå har en tilsvarende myndighet når det gjelder tilbudene av boform, pleie og omsorg. Dette betyr vel å merke at sykehuspersonalet ikke kan bestemme noe om oppfølgingen i kommunene, for eksempel love sykehjemsbehandling.

Kostnader og ressurser: Ressursmangel skal aldri være en grunn til at kommuner eller sykehus ikke følger opp sin del av ansvaret for helse, omsorg og støtte til pasienten.

Byråkrati og administrasjon: Liggetiden skal ikke forlenges på grunn av forsinkelser i vårdplaneringen.

\section{ELVIS-systemet}

Vårdplanering er nøkkelen til en god samhandling, og inngår som den viktigste del av utskrivingsprosessen fra sykehus til kommune for disse pasientene. Dersom den behandlende legen på sykehuset vurderer at det vil foreligge et pleiebehov i kommunen etter utskrivelsen skal det sendes et innskrivningsmelding som forteller 
at en slik pasient er innskrevet og vil trenger etterbehandling i kommunen ved utskriving. Denne meldingen skal inneholde navnet på behandlende sykehuslege. Kommunen har på sin side plikt til å gi sykehusene en oppdatert liste over den person som har ansvaret for å motta og følge opp slike meldinger. Dersom pasienten allerede har mottatt kommunale pleietjenester, skal detaljerte opplysninger om disse, samt en ADL-status oversendes fra kommunen til sykehuset. Her skal pasientens samtykke først innhentes.

I Sverige er vårdplanering første skritt i utskrivingsprosessen og starter med at sykehuset sender en innkalling til et fellesmøte som skal gjennomføre en vårdplanering. Dette skjer via et eget elektronisk system til kontaktpersonen i kommunen (ELVIS - systemet). Et viktig krav er at kommunen skal svare på innkallelsen senest dagen etter at innkallingen er mottatt av kommunen. Videre kreves det at vårdplanen skal utformes i samarbeid mellom den ansvarlige saksbehandler i begge forvaltningsnivåer, og i tillegg skal pasienten eller en nærstående delta i møtet.

\section{Dalarna}

I Dalarna er det store avstander fra sykehuset til noen av kommunene, derfor kan vårdplaneringen påbegynnes eller gjennomføres som videokonferanse eller på telefon. Vårdplanen skal sammenfattes skriftlig av en fagperson ved sykehuset. Dersom det er behov for rehabilitering eller hjelpemidler etter utskrivingen skal en kompetent person som representerer hjemkommunen delta i sammenfatningen. Selve vårdplanen er et omfattende dokument som skal inneholde minimum ti punkter som fastslår ansvar, innhold og oppfølging. De viktigste er:

, hva som skal gjøres og hvem som er ansvarlig

, behandlende lege i kommunen som også får ansvar for justeringer av planen dersom behovene endres

> om pasienten eller pårørende har vært delaktig i planen

> at det er enighet om planen i begge forvaltningsnivåer (krever formell signering)

Ved utskriving skal den behandlende lege på sykehuset oversende en utskrivingsmelding til de navngitte personer i kommunen som har ansvar for de ulike tiltakene som vårdplanen inneholder. I tillegg skal medisinsk informasjon og legemiddelliste medfølge pasienten, samt medisiner for minst tre døgns forbruk. Kommunens ansvar etter at vårdplanen er utarbeidet og nedskrevet, er å prioritere pasientene etter behov og i forhold til kommunens behandlingskapasitet. Prioritering av plassfordeling skjer ut fra betalingsansvar og pasientens helsetilstand.

Kommunens betalingsansvar for ferdigbehandlete pasienter inntrer fem dager etter at kommunen har kvittert for innkalling til vårdplanering. Dette gjelder selv om det ikke blir opprettet noen «vårdplan». Dette kan kun fravikes dersom den medisinske tilstand blir forverret i mellomtiden, slik at det trengs en ny plan.

Ved uenighet om samordningen av behandlingen mellom de to forvaltningsnivåene skal det utarbeides en avviksrapport som har forslag til forbedringer. Den skal sendes til ansvarlig sjef i Dalarna len og til medisinsk ansvarlig sykepleiesjef i kommunen.

\section{Sammenlikning med Norge}

Dalarna har tre akuttsykehus som skriver ut pasienter til kommunene, mens Østfold har to; Fredrikstad og Moss. Dalarna len omfatter 14 kommuner og har nesten 280000 innbyggere mot 275000 innbyggere i Østfold som har 18 kommuner. Dermed er disse områdene relativt sammenliknbare, bortsett fra at av-

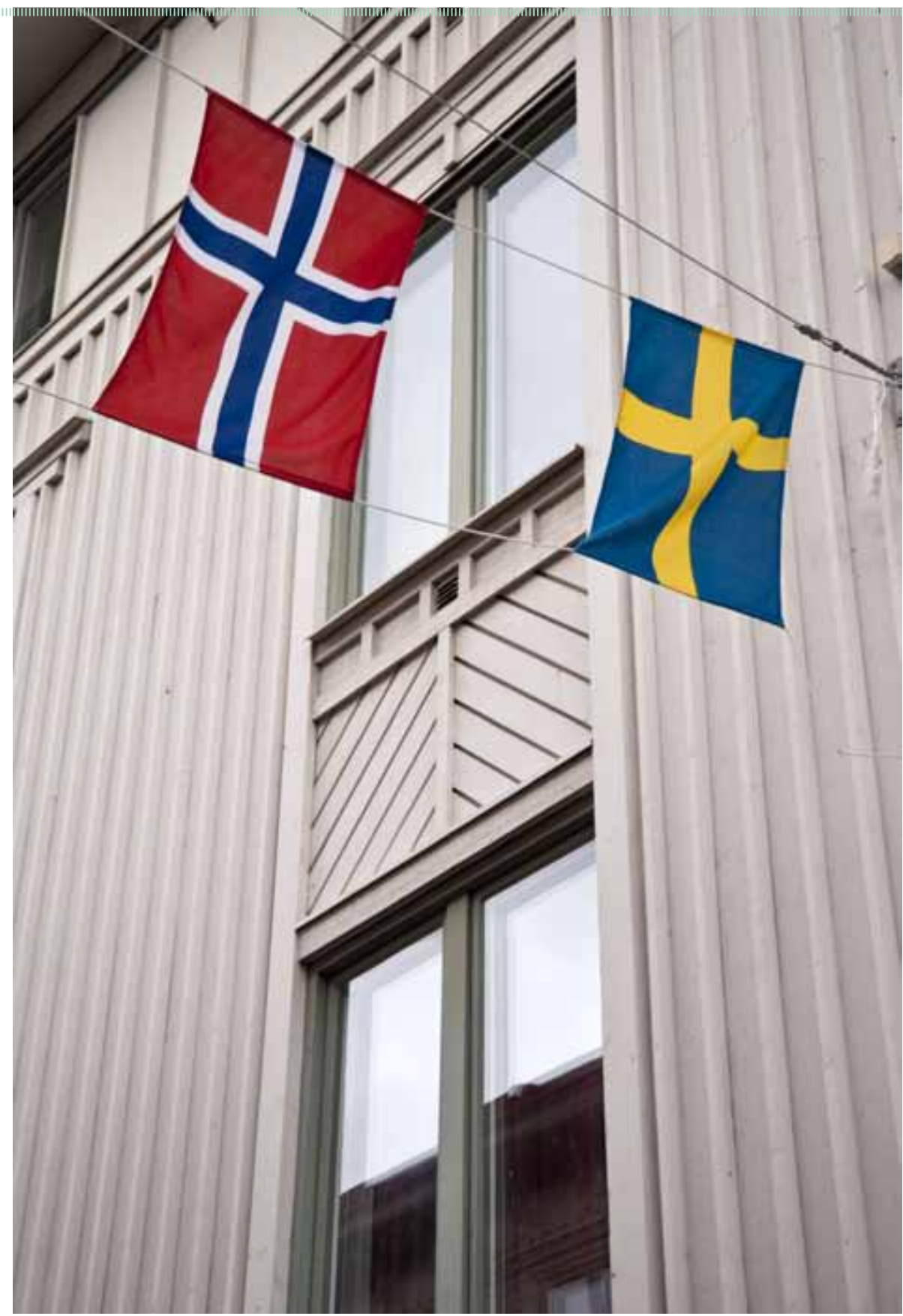

standene er noe større i Dalarna, noe som ikke er noen fordel for samhandlingen.

I Østfold er det opprettet et administrativt samarbeidsutvalg som i 2007 fastsatte rutiner og meldeskjemaer. Dette er i ettertid blitt evaluert og revidert, senest i november 2009 (2). Samhandlingen styres gjennom et samhandlingsdokument med fire skjemaer (3).

I begge land gjelder disse rutinene kun for den pasientgruppen der det er behov for samhandling etter utskriving. Det er viktige systemforskjeller mellom våre land knyttet til to avgjørende faser i samhandlingen: Inn- og utskriving i sykehus.

\section{Informasjonsflyt}

Felles for begge land er at det er en lege som er ansvarlig for innleggelsene. Dersom pasienten tidligere har fătt pleie- og omsorgstjenester fra kommunen eller antas å trenge det etter utskriving, sendes det et varsel til kommunen. I Sverige skjer dette elektronisk via ELVIS-systemet eller en faks, og inneholder en melding om hvem som er behandlende sykehuslege. Innleggende lege gir opplysninger om sykdommen, funksjonsnivå, pasientens bruk av det kommunale hjelpeapparatet, samt vurdering av tjenestebehov. Videre skal det informeres om hvem som er kontaktperson i førstelinjetjenesten.
BEST I øST? Norge har mye å lære av svenskene som er godt i gang med en tilsynelatende velfungerende samhandlingsreform. Foto: Scanpix.

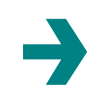


I Østfold skal kommunehelsetjenesten oversende tilsvarende opplysninger på et standardskjema (Meldeskjema 1).

\section{Utskriving og oppfølging}

I Østfold styres utskrivingsrutinene av «Forskrift om betaling for utskrivingsklare pasienter» (4) og informasjonen fra sykehuset til kommunene bestemmes av tre meldeskjemaer. Ett skjema inneholder legeopplysninger, og ett inneholder sykepleieopplysninger. Det tredje er «Sjekkliste for utreise for somatiske pasienter med behov for kommunale tjenester» som er en detaljert liste som utfylles av en sykepleier på sykehuset.

I Østfold inntreffer betalingsansvaret ti dager etter sykehusets fastsettelse av ferdigbehandletdato. Fram til 1.1. 2012 er døgnpri-

\section{Det er viktige systemforskjeller mellom våre land knyttet til to avgjørende faser i sam- handlingen: Inn- og utskriving i sykehus.}

sen 1600 kroner, men deretter vil kommunenes betalingsansvar starte fra dag én og prisen vil øke til 4000 kroner.

I Dalarne inntrer kommunens betalingsplikt fem dager etter den meldte utskrivingsdato (som bestemmes under vårdplaneringen) og i 2011 er døgnpris 4100 svenske kroner.

\section{Oppsummering}

Samhandlingen i Dalarna og Østfold er bygd på de samme prinsipper. Det grunnleggende trekk er at en sykehuslege bestemmer når pasienten er utskrivingsklar. Det er samhandlingen om medisinske opplysninger og de tilhørende vurderinger som avgjør hva som skal skje videre med disse pasientene. Her er det viktige forskjeller mellom Sverige og Norge, først og fremst gjelder dette samarbeidet og arbeidsfordelingen ved utskriving. Gjennom vårdplanerings-systemet har kommune, pasient og pårørende en sterkere rolle i Sverige. Her er de sterkere og mer aktivt involvert i utskrivingsprosessen. Det er spesielt viktig at begge parter kan opptre likeverdig i et møte som skal ende opp med et omforent møte med skriftlige vedtak fra begge parter.

En annen viktig forskjell er den manglende eller begrensete involvering av fysio- og ergoterapeuter på kommunenivå i Norge. Dette betyr at opptrenings- og rehabiliteringspotensialet ikke blir vektlagt i samme grad som i Sverige, og dette vil trolig bidra til større fokus på pleietyngde og tilhørende behov som fortrenger opptrening og rehabilitering i kommunal regi.

I Norge synes sykehuset å ha mer styring med utskrivingsprosessen, mens kommunen får rollen som den svakeste part. Dette kan bidra til konfliktsituasjoner dersom sykehuset vurderer at pasienten bør få varig opphold på sykehjemsnivå, mens kommunens vurdering er et lavere nivå. Dette unngås i Sverige gjennom «vårdplaneringen» som forutsetter konsensus om hver enkelt pasient. I tillegg blir pasient og pårørende invitert som selvstendige aktører i selve møtet, og får derved en mulighet til å påvirke vedtaket.

\section{Tre ting å lære av}

1. I Norge er det er behov for et elektronisk informasjons- og meldesystem slik det fungerer i Sverige. Dette er særlig påkrevet når kommunen får et betalingsansvar allerede fra dag én når sykehuset gir melding om utskrivingsdato.
2. Samhandlingen i Norge bør i sterkere grad baseres på en samordning, der kommunene blir suverene i vurderingen av hvilke tjenester som skal gis etter utskriving, mens sykehuset bestemmer utskrivingsdato. I dag er både det norske og svenske systemet «skjevt» når det gjelder samhandling fordi sykehuset kun vurderer behovet til den enkelte pasient som skal utskrives. Kommunen må altså ta den helhetlige vurderingen, og prioritere behovene til den enkelte pasient i forhold til behovene til alle pasientene som behandles i kommunen på samhandlingstidspunktet.

3. I Sverige involveres pasienten og de pårørende i vårdplanleggingen slik at de får tilgang til de faglige vurderingene før beslutningen om behandlingsnivå etter utskrivingen fattes. Derved unngås trolig en del av de klagene og den frustrasjon som de pårørende målbærer og som ikke så sjelden havner i mediene.

\section{Faresignaler}

Et viktig spørsmål er om en kan generalisere ut fra de funn som her er beskrevet. Selv om det trolig er noe variasjon mellom de ulike regioner i Norge, er selve samhandlingsreformen basert på sentral styring. Dette må en ta hensyn til ved sammenlikninger.

Hva er faresignalene for den norske reformen som kan identifiseres når en sammenlikner det norske systemet med den svenske ordningen som har fungert i lengre tid, og som ifølge fagfolk på kommunenivå i Sverige fungerer bra? Etter min vurdering er det i hovedsak tre potensielle problemer:

\section{Kommuneøkonomien}

Allerede i dag er det mange kommuner som ikke klarer å overta utskrivingsklare pasienter på det tidspunkt som sykehuset bestemmer. Når betalingstidspunktet har et innslag fra dag én, blir konsekvensene ganske betydelige i noen kommuner. Mange av disse har driftsproblemer i eldreomsorgen allerede i dag, og fra 2012 vil de få et økonomisk problem i tillegg. Dette kan på lengre sikt bidra til store forskjeller mellom kommunenes tilbud av pleie- og omsorgstjenester. De er betydelige allerede i dag, og Samhandlingsreformen vil garantert bidra til at de vil øke. Hvor store forskjeller vil de sentrale helsemyndigheter akseptere når diskusjonen handler om innhold og kvalitet i norsk eldreomsorg?

\section{Helsebyråkrati}

$\varnothing \mathrm{kt}$ risiko for at pasienten i enda sterkere grad enn før opplever å bli en kasteball i et helsebyråkrati som vil være uforståelig for mange legfolk og pårørende. Dette vil trolig føre til økte oppslag i media.

\section{Rehabilitering}

Mange av de utskrivingsklare pasienten vil trenge et rehabiliteringsopplegg i hjemkommunen for å kunne bo utenfor sykehjem. Det tilbudet er mye sterkere utbygd i våre naboland, og er kanskje en forutsetning for at denne type samhandling fungerer i praksis. Hva vil skje i norske kommuner som ikke har et tilfredsstillende tilbud på dette området? III

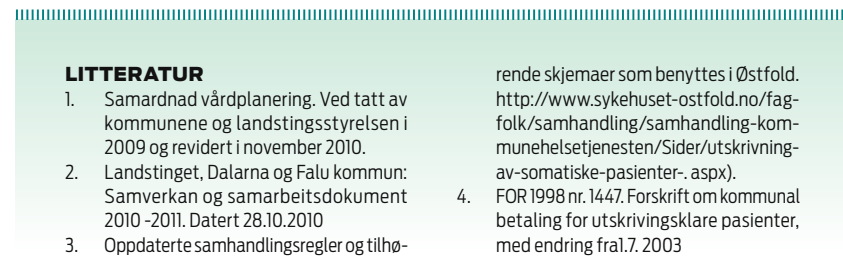

